\title{
Is it the "outstanding universal value" of heritage really global?
}

\author{
Measuring reputation using social media
}

\author{
Vasco Monteiro, Marco Painho \\ ISEGI, Universidade Nova de Lisboa \\ Lisboa, Portugal \\ d2012167@isegi.unl.pt, painho@isegi.unl.pt
}

\author{
Eric de Noronha Vaz \\ Ryerson University \\ Toronto, Ontario, Canada \\ evaz@geography.ryerson.ca
}

Abstract-Web 2.0 and social media play an important role nowadays in our society, not only from a user perspective, but also on an academic perspective. The data and information production based on the user-generated content is an important source to conduct scientific studies, specially the new geospatial information that exists due to the widespread of technological devices that capture the geospatial data. The main objective of this research is to assess if we can measure the brand awareness, with a focus in the reputation component, using geospatial usergenerated content with an approach as a geographic problem. In this paper is identified the main research question and objectives, the methodological approach and the expected results regarding this Doctorate Thesis in Information Management.

Keywords: geographic information, social media, web 2.0, citizen sensing, ambient information systems, GIS, world heritage, brand awareness, reputation

\section{INTRODUCTION}

Heritage sites are preserved to pass to the next generation and are a useful tool to show the continuous and long-lasting identity of a country [1].

The English Heritage, in its strategy for 2005-2010 has created a heritage cycle, which embodies the motto "make the past part of our future", by understanding, valuing, carrying and enjoying it "Fig.1" [30].

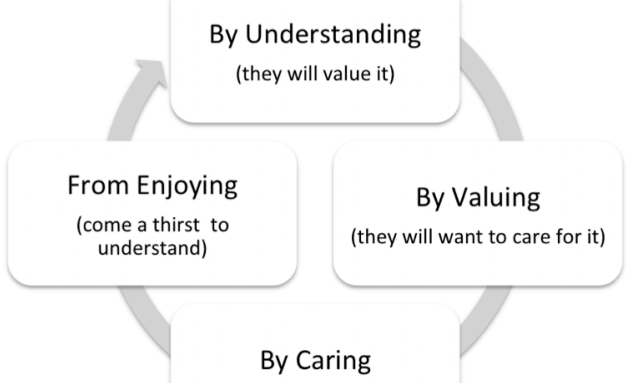

Figure 1. Heritage Cycle - adapted from S. Thurley (2005)
But, the concern about the protection of heritage initiatives dates back from the nineteenth century, with the aim of protecting nature and landscapes, with the creation of the first private societies for the protection of wildlife, natural sites and nice scenery [16].

One of the most important initiatives to protect heritage sites was developed by the United Nations Educational, Scientific and Cultural Organization (UNESCO), that adopted the Convention Concerning the Protection of the World Cultural and Natural Heritage in their general conference in 1972 [1], [16], [23], [25].

Under this convention the kind of natural and cultural resources considered to represent a common heritage (that should be protected and treasured as unique testimony of our past -heritage that is considered of outstanding universal value) was defined. [25]

Since the adoption of the convention, 40 years ago, the World Heritage List has had 962 properties inscribed - 745 cultural, 188 natural and 29 mixed sites - located in 157 State Parties [34]. The inscription of a site in this list is for many countries, as icons, a matter of status [12]; in particular, its designation as a World Heritage site is seen as a desirable symbol and as a tool for campaigns to increase tourism [23]: "the inscription of a site on the World Heritage List brings an inevitable and welcomed awareness and curiosity about the site and its outstanding values" [33].

One of the most beneficial consequences of being on World Heritage list is the direction of attention to the sites, along with the specific protection provided by the collective international effort to safeguard our planet from destruction (like in global environment and climate change issues), which attracts the attention of various actors (from the general public to public decision-makers, potential donors and fro-profit firms), due to the resonance produced in the media [3].

The World Heritage list currently includes 38 properties that are considerer to be at risk and are included in the List of World Heritage in danger. This list was created to inform the international community in circumstances in which the 
characteristics for the inscribed site are threatened and need corrective actions. The threats/risks could be armed conflicts and war, earthquakes and other natural hazards, as well as uncontrolled urbanization or tourism development, to cite some examples [34].

In terms of information systems, the uses of Geographic Information Systems (GIS) and remote sensing have an important tool for management and conservation of the World Heritage Sites. These technologies could help national states to manage their properties by having better land-use maps and well-defined boundaries in their sites [21], [25].

More specifically, in the tourism area, the application of GIS as a tool for a sustainable tourism planning plays an important role to examine impacts and to assist in the decisionmaking process [31].

Other systems as the Geospatial Content Management System (GeoCMS), an advance form of Information Management Systems with GIS capabilities, are becoming more popular in the field of cultural heritage [24]. In table 1 are some examples of applications to the cultural heritage field; the most part of the systems are openly accessible to the public but in some platforms an additional registration is needed.

TABLE I. INFORMATION MANAGEMENT SYSTEMS WITH GIS IN Cultural HERITAGE FiELD

\begin{tabular}{|c|c|c|c|}
\hline Name & Objective & Accessibility & Link \\
\hline $\begin{array}{l}\text { UNESCO } \\
\text { World Heritage } \\
\text { Centre }\end{array}$ & $\begin{array}{l}\text { World Heritage } \\
\text { List and their } \\
\text { related } \\
\text { activities. }\end{array}$ & $\begin{array}{l}\text { Shared } \\
\text { Public }\end{array}$ & $\begin{array}{l}\text { http://whc.un } \\
\text { esco.org/ }\end{array}$ \\
\hline $\begin{array}{l}\text { Middle Eastern } \\
\text { Geodatabase for } \\
\text { Antiquities } \\
\text { (Mega Jordan) }\end{array}$ & $\begin{array}{l}\text { Database of } \\
\text { archaeological } \\
\text { site in Jordan }\end{array}$ & $\begin{array}{l}\text { Restricted } \\
\text { Access }\end{array}$ & $\begin{array}{l}\text { http://megajo } \\
\text { rdan.org/ }\end{array}$ \\
\hline $\begin{array}{l}\text { Global Heritage } \\
\text { Network (GHN) }\end{array}$ & $\begin{array}{l}\text { Early Warning } \\
\text { and } \\
\text { Collaborative } \\
\text { Solutions } \\
\text { Platforms }\end{array}$ & $\begin{array}{l}\text { Open Access } \\
\text { and restricted } \\
\text { community } \\
\text { access }\end{array}$ & $\begin{array}{l}\text { http://ghn.glo } \\
\text { balheritagefu } \\
\text { nd.org/ }\end{array}$ \\
\hline Berlin Wall & $\begin{array}{l}\text { Interactive GIS } \\
\text { documenting the } \\
\text { Berlin Wall }\end{array}$ & $\begin{array}{l}\text { Shared } \\
\text { Public }\end{array}$ & $\begin{array}{l}\text { http://denkm } \\
\text { allandschaft- } \\
\text { berliner- } \\
\text { mauer.de/ }\end{array}$ \\
\hline $\begin{array}{l}\text { Heritech for the } \\
\text { city of Biograd } \\
\text { na Moru }\end{array}$ & $\begin{array}{l}\text { GeoICT for the } \\
\text { preservation and } \\
\text { promotion of } \\
\text { Croatian } \\
\text { Cultural } \\
\text { Heritage }\end{array}$ & $\begin{array}{l}\text { Shared } \\
\text { Public }\end{array}$ & $\begin{array}{l}\text { http://www.b } \\
\text { iograd- } \\
\text { heritech.hr/ }\end{array}$ \\
\hline $\begin{array}{l}\text { Monument } \\
\text { Watch Flanders }\end{array}$ & $\begin{array}{l}\text { Monitoring and } \\
\text { maintenance } \\
\text { system for the } \\
\text { Built Cultural } \\
\text { Heritage in the } \\
\text { Flemish Region, } \\
\text { Belgium }\end{array}$ & $\begin{array}{l}\text { Shared } \\
\text { Public }\end{array}$ & $\begin{array}{l}\text { http://www. } \\
\text { monumenten } \\
\text { wacht.be/ }\end{array}$ \\
\hline
\end{tabular}

It is well known that nowadays a conflict exists between heritage protection and other issues, such as tourism development. This conflict is present in large number of countries but is even more pronounced in developing countries. Furthermore, countries use the world heritage sites as marketing tools to attract tourists, who could lead to issues related to sustainability of tourism development [23].

Due the increase, in heritage sites, of tourism pressure as well as others risk factors (e.g. urban growth, climate change, and other natural/human hazards), it is important that all the stakeholders involved in the heritage management and conservation have data/information within their information systems that support their decisions.

Of particular interest, are the latest developments on information and communication technologies and the increasing of Global Positioning System (GPS) equipped cellular phones, tablets and cameras, which increased substantially the volume of information related to the movements of people [9], which could be used as data to support decision-making on heritage management.

As pointed by Goodchild, we are voluntary sensors, six billion observers in the world of web 2.0, equipped with means to upload our observations [19], [20], and in the last years the development of location-based social media has moved the social media to the real world [6]; giving opportunities to understand the access and use of public spaces or specific needs of a community, using the user-generated geospatial data [1], [8]. The use of this type of data/information, could add value to the decision-making process of all stakeholders that manage a heritage site, in a daily basis or in a risk management situation.

In fact, most local authorities in the world face a lack of information on tourist dynamics [9]. The increase of the tourism impact on heritage, especially in urban areas, requires more precise and dynamic understanding of tourist behaviors and movements at both micro and macro scales [38].

The role of social media in tourism, travel information and in destination marketing is a growing area of study in the last years, focus on understanding tourist behaviors and the challenges and opportunities in destinations marketing (e.g. awareness, electronic word-of-mouth (eWOM), among others) [13], [16], [28], [36], [39].

\section{RESEARCH PROBLEM IDENTIFICATION AND OBJECTIVES}

In this context, this thesis will have a holistic approach in regarding the reputation of a specific heritage site, measuring both the tourism pressure made on the site and in its surroundings and the data/information exchanged worldwide concerning that specific site.

The research question that the thesis will try to address is:

- Can the user-generated content with geographic information be used to modeling the reputation of a world heritage worldwide?

With this aim in mind, the following objectives are proposed:

- Identify the information types (feeds, images, videos, among others) that people share with others, regarding heritage, and more specifically world heritage;

- Identify the spatial distribution of the information shared, according to the following criteria: shared in its 
spatial location or outside, shared by non-residents or residents in the country, sharing profile by country, among others. Temporal dimension will be also analyzed (pre-nomination, post-nomination and when listed);

- Identify which heritage sites are considered universal icons, i.e. which heritage is more shared, and understand the difference between the spatial distribution inside and outside its specific spatial location;

- Identify if the heritage that is in already the world heritage list and that currently present in the tentative world heritage list have different sharing profiles and therefore, understand if the world heritage list fosters the sites reputation, i.e., if there is a different impact as result of belonging or not to the list;

- Identify if specific events (e.g. wars, natural disasters, among others) trigger different behaviors on sharing information regarding heritage and if this global awareness could be useful for the site protection.

\section{METHODOLOGICAL APPROACH}

Two main parts compose the proposed methodological approach work: first, literature review on heritage and social media; and secondly the empirical work to address the objectives mentioned above.

\section{A. Literature review}

The literature review will focus on the following issues:

- Heritage context, and specially world heritage context, its problematic and socio-economic issues. More specifically the issues relating to tourism, brand awareness, image and reputation will be address [3], [4], [6], [15], [16], [27], [32], [35], [37];

- Citizen sensing, Volunteered Geographic Information (VGI), Involuntary Geographic Information (iVGI) and Ambient Geographic Information (AGI); and relation with web 2.0 and social media [5], [20], [38], [1], [6], [8], [19], [21], [29];

- Web 2.0, social media and behavior of users definition of users, activity and participation and its applications in tourism [13], [16], [28], [36], [39];

- Geographic Information Systems (GIS) and uses in heritage and tourism, more specifically in world heritage sites [21], [24], [25], [31].

\section{B. Empirical work}

In table II, the specific methods that will be employed to address specific objectives are shown. Further literature review will be done for specific methods or data retrieved in social media, such as micro blogging, social networks, reviews/travel sites, photo sites (e.g. Twitter, Facebook, Tripadvisor, Flickr, among others) [11], [13], [14], [26].

\section{TABLE II. OBJECTIVES AND METHODS}

\begin{tabular}{|c|c|}
\hline Objective & Method \\
\hline $\begin{array}{l}\text { Identify the information types (feeds, } \\
\text { images, videos, among others) that } \\
\text { people share with others, regarding } \\
\text { heritage, and more specifically world } \\
\text { heritage }\end{array}$ & $\begin{array}{l}\text { - Information retrieval from } \\
\text { social media: streaming } \\
\text { APIs, Web semantics and } \\
\text { text mining } \\
\text { - Data segmentation }\end{array}$ \\
\hline $\begin{array}{l}\text { Identify the spatial distribution of the } \\
\text { information shared, according to the } \\
\text { following criteria: } \\
\text { - Shared in its spatial } \\
\text { location or outside; } \\
\text { - Shared by non-residents or } \\
\text { residents in the country: } \\
\text { - Sharing profile by country; } \\
\text { - Among others. } \\
\text { Temporal dimension will be also } \\
\text { analyzed regarding the status of the } \\
\text { heritage (pre-nomination to World } \\
\text { Heritage, post-nomination and when } \\
\text { listed). }\end{array}$ & $\begin{array}{l}\text { - Data segmentation } \\
\text { - GIS and Spatial Analysis, } \\
\text { Geovisual analytics }\end{array}$ \\
\hline $\begin{array}{l}\text { Identify which heritage sites are } \\
\text { considered universal icons, i.e. which } \\
\text { heritage is more shared, and } \\
\text { understand the difference between the } \\
\text { spatial distribution inside and outside } \\
\text { its specific spatial location }\end{array}$ & $\begin{array}{l}\text { - Data segmentation } \\
\text { - GIS and Spatial Analysis, } \\
\text { Geovisual analytics }\end{array}$ \\
\hline $\begin{array}{l}\text { Identify if exists different sharing } \\
\text { profiles for the heritage with the World } \\
\text { Heritage brand and those that are in the } \\
\text { tentative list and therefore, understand } \\
\text { if the world heritage list fosters the } \\
\text { sites reputation, i.e., if there is a } \\
\text { different impact as result of belonging } \\
\text { or not to the list }\end{array}$ & $\begin{array}{l}\text { - Data segmentation } \\
\text { - GIS and Spatial Analysis, } \\
\text { Geovisual analytics }\end{array}$ \\
\hline $\begin{array}{l}\text { Identify if specific events (e.g. wars, } \\
\text { natural disasters, among others) trigger } \\
\text { different behaviors on sharing } \\
\text { information regarding heritage and if } \\
\text { this global awareness could be useful } \\
\text { for the site protection }\end{array}$ & $\begin{array}{l}\text { - Convenience Sampling to } \\
\text { choose heritage sites with } \\
\text { specific events } \\
\text { - GIS and Spatial Analysis, } \\
\text { Geovisual analytics }\end{array}$ \\
\hline
\end{tabular}

As a posterior phase in the empirical work it is intended to do a second validation of the proposed model constructing an artifact, composed by a Web GIS application and a dashboard application.

\section{EXPECTED RESULTS}

With this research, it is intended:

- To develop a theoretical analysis model of the heritage site reputation, using social media - identifying the relevant dimensions, factors and variables, in order for the model be applicable in the future without technology constraints;

- To develop the data model of integration of the data mentioned above with the information systems used in heritage management and monitoring, especially the geographic information systems;

- To make available a Web GIS with the different layers of information;

- And to create a series of dashboards to support the stakeholders of the heritage sites. 
For each result mentioned above it is intended to make available the results of the research by publishing in scientific journals and by participating in conferences and publishing in its proceedings.

\section{REFERENCES}

[1] A. Stefanidis, A. Crooks, and J. Radzikowski, "Harvesting ambient geospatial information from social media feeds," GeoJournal, 2011, pp. $1-20$.

[2] B. J. Van der Aa, "Preserving the heritage of humanity? Obtaining world heritage status and the impacts of listing," 2005. Unpublished Ph. D. thesis, University of Groningen, Groningen.

[3] B. S. Frey and L. Steiner, L, "World Heritage List: does it make sense?," International Journal of Cultural Policy, vol. 17, no. 5, 2011, pp. 555573.

[4] C. de Cesari, "World Heritage and mosaic universalism. view from Palestine ," Journal of Social Archaeolog, vol. 10, no. 3, 2010, pp. 299324

[5] D. Hardy, J. Frew, and M. Goodchild, "Volunteered geographic information production as a spatial process," International Journal of Geographical Information Science, vol. 26, no. 7, 2012, pp. 1191-1212.

[6] D. Sui, and M. Goodchild, "The convergence of GIS and social media: challenges for GIScience," International Journal of Geographical Information Science, 2011, vol. 25, no. 11, pp. 1737-1748.

[7] F. Bandarin, World heritage: challenges for the millennium. Unesco, World Heritage Centre, 2007.

[8] F. Fischer, "A New but Delicate Geographic Data Source VGI as Big Data," GeoInformatics, 2012, pp. 46-47.

[9] F. Girardin, F. Dal Fiore, C. Ratti, and J. Blat, "Leveraging explicitly disclosed location information to understand tourist dynamics: a case study," Journal of Location Based Services, vol. 2, no. 1, 2008, pp. 4156.

[10] H. Hazen, "“Of outstanding universal value": The challenge of scale in applying the World Heritage Convention at national parks in the US," Geoforum, vol. 39, no. 1, 2008, pp. 252-264.

[11] H. Kawakubo and Y. Keiji, "GeoVisualRank: a ranking method of geotagged imagesconsidering visual similarity and geo-location proximity."Proceedings of the 20th international conference companion on World wide web. ACM, 2011.

[12] ICOMOS, Tourism at World Heritage Cultural Sites: The site manager's handbook (2nd ed). Madrid: World Tourism Organization, 1993

[13] J. Miguéns, R. Baggio, and C. Costa. "Social media and tourism destinations: TripAdvisor case study." Advances in Tourism Research, 2008, pp. 26-28

[14] J. Van Dijck, "Flickr and the culture of connectivity: Sharing views, experiences, memories," Memory Studies, vol. 4, no. 4, 2011, pp. 401415

[15] J. W. Thorsell, "World Heritage Convention: Effectiveness 1992-2002 and Lessons for Governance," World Heritage Convention, 2003.

[16] L. Mich, "Towards a Web 2.0 presence model for tourism destination management organizations," In eChallenges, 2010, IEEE, 2010, pp. 1-8.

[17] M. A. Elliott, and V. Schmutz. "World heritage: Constructing a universal cultural order." Poetics, vol. 40, no. 3, 2012, pp. 256-277.

[18] M. Antrop, "Why landscapes of the past are important for the future," Landscape and urban planning, vol. 70,no. 1, pp. 21-34, 2005

[19] M. Goodchild, "Citizens as sensors: the world of volunteered geography," GeoJournal, 69 (4), 211-221.

[20] M. Goodchild, "Citizens as voluntary sensors: spatial data infrastructure in the world of web 2.0," International Journal of Spatial Data Infrastructures Research, vol. 2, 2007, pp. 24-32

[21] M. Haklay, A. Singelton, and C. Parker, "Web mapping 2.0: the neogeography of the GeoWeb," Geography Compass, vol. 2, no.6, 2008, pp. 2011-2039.
[22] M. Hernandez, "Use of satellite imagery to support the World Heritage Convention," Paper presented at 23rd Symposium of the European Association of Remote Sensing Laboratories (EARSEL). Belgium: Ghent, 2004

[23] M. Li, B. Wu, and L. Cai. "Tourism development of World Heritage Sites in China: A geographic perspective." Tourism Management, vol. 29, no. 2, 2008, pp. 308-319.

[24] O. Vileikis et al.,"Information Management Systems for Monitoring and Documenting World Heritage-The Silk Roads Chris," International Archives of Photogrammetry and Remote Sensing, 2012

[25] P. De Maeyer., L. De Temmerman, P. Bogaert, L. Vansteenvoort, R. Goossens, and M. Binard, "The benefits of the remote sensing for conservation and monitoring world heritage sites," Paper presented at 23rd Symposium of the European Association of Remote Sensing Laboratories (EARSEL). Belgium: Ghent, 2004

[26] P. Jankowski, N. Andrienko, G. Andrienko, and S. Kisilevich, "Discovering landmark preferences and movement patterns from photo postings," Transactions in GIS, vol. 14, no. 6, 2010, pp. 833-852.

[27] R. Jones and B. Shaw, "Thinking locally, acting globally? Stakeholder conflicts over UNESCO World Heritage inscription in Western Australia,", vol. 7, no. 1, 2012, pp. 83-96

[28] R. Schegg, A. Liebrich, M. Scaglione, and S. F. S. Ahmad. "An exploratory field study of Web 2.0 in Tourism." Information and Communication Technologies in Tourism 2008, 2008, pp. 152-163.

[29] S. Elwood, M. Goodchild, and D. Z. Sui, "Researching Volunteered Geographic Information: Spatial Data, Geographic Research, and New Social Practice," Annals of the Association of American Geographers, vol. 102 , no. 3, 2011, pp. 571-590.

[30] S. Thurley, "Into the future. Our stategy for 2005-2010." Conservation Bulletin [English Heritage], 2005

[31] T. Bahaire and M. Elliott-White, "The application of geographical information systems (GIS) in sustainable tourism planning: A review," Journal of Sustainable Tourism, vol. 7, no. 2, pp. 159-174, 1999

[32] T. Rakic, and D. Chambers, "World Heritage: exploring the tension between the national and the 'universal'." Journal of Heritage Tourism, vol. 2, no. 3, 2008, pp. 145-155.

[33] UNESCO (2013, Feb). World Heritage Information Kit. [Online] Available: http://whc.unesco.org/uploads/activities/documents/activity567-1.pdf

[34] UNESCO (2013, Feb). World Heritage Centre. [Online] Available: http://whc.unesco.org/

[35] UNESCO. Intergovernmental Committee for the Protection of the World Cultural and Natural Heritage. (2012). Operational Guidelines for the Implementation of the World Heritage Convention: Intergovernmental Committee for the Protection of the World Cultural and Natural Heritage. UNESCO, 2012.

[36] W. Lange-Faria, and S. Elliot, "Understanding the role of social media in destination marketing," Tourismos: an International Multidisciplinary Journal of Tourism, vol. 7, no. 1, 2012, pp. 193-211.

[37] Y. Poria, A. Reichel, and R. Cohen, "World Heritage Site-Is It an Effective Brand Name? A Case Study of a Religious Heritage Site," Journal of Travel Research, vol. 50, no. 5, 2011, pp. 482-495.

[38] Y. Yoshimura, F. Girardin, J. P. Carrascal, C. Ratti, J. Blat, M. Fuchs, F. Ricci, and L. Cantoni. "New tools for studying visitor behaviours in museums: a case study at the Louvre." In Information and Communication Technologies in Tourism 2012. Proceedings of the International conference in Helsingborg (ENTER 2012). Mörlenback: Springer Wien NewYork. This entry was posted on February, vol. 6. in: ENTER'12 19 th International Conference on Information Technology and Travel \& Tourism ENTER 2012, 2012.

[39] Z. Xiang, and U. Gretzel. "Role of social media in online travel information search," Tourism Management, vol. 31, no. 2, 2010, pp. $179-188$. 